\title{
Comprehensive Analysis of Cultural Confidence Education and Ideological and Political Education
}

\author{
Shuqi Li \\ Xi'an Peihua University, Xi’an, 710000, China
}

Keywords: Cultural confidence, Ideological and political education, Integration Methods

\begin{abstract}
College students are important forces to inherit and innovate the national culture. There is a close relationship between college students' cultural confidence education and ideological and political education. This paper analyses the current situations and causes of integration of cultural confidence education and ideological and political education in the current stage, and proposes the suggestions of cultural confidence and ideological and political education to improve the attraction of ideological and political education and to shape the cultural self-confidence of college students.
\end{abstract}

\section{Introduction}

In higher education, ideological and political education mainly bears the tasks of cultural edification and ideological education [1]. It has far-reaching influence on Establishing College Students' cultural confidence and is the key to cultivate college students' cultural confidence. At the same time, the shaping of college Students' cultural confidence has a direct impact on the effectiveness of Ideological and political work in Colleges and universities. There is a profound internal relationship between the two, which are mainly embodied in the similarities and complementing of the two. Cultural confidence comes from a long and splendid traditional culture which is mainly composed of patriotism and self-improvement. It also comes from the advanced culture of socialism with Chinese characteristics. Ideological and political education is an important form of cultural education as a guide and promotion of people's political consciousness and ideological state. Both are homologous in the content. Cultural confidence can guide people to observe the world, understand the world and grasp the world by means of culture, to enhance people's personal quality, and further enhance their national quality and enhance their sense of responsibility. Obviously, the cultural function of Ideological and political education, it aims to moral education, political knowledge and ideology education content, pointing to the distinctive shape service in socialist construction rule of self, to enhance the individual and even the whole nation's ideological and political qualities. It can be found that both serve the development of the members of the society and the development of the nation, and they are compatible with their functions. The confrontation between various cultural forms, social thoughts and ideology in the ideological and cultural field of our country is becoming more and more intense. Currently, cultural confidence is particularly important in the comprehensive national strength competition among great powers because of its direct connection with the cultural development and spiritual outlook of a country. It is an inevitable requirement for the ideological and political education in the new period to cultivate and enhance the cultural confidence of college students through the ideological and political work in Colleges and universities.

\section{Current Situations and Causes of Integration of Cultural Confidence Education and Ideological and Political Education}

\subsection{Current Situations}

Under the current educational model, the essence of the traditional culture is gradually in the 
vision of Ideological and political education [2]. Under the influence of all kinds of subjective and objective factors, the traditional culture education in China basically desalination the stage of Ideological and political education, and it is difficult to play its due role. Although contemporary college students are concerned about Chinese traditional culture, they lack self-awareness of traditional culture learning and research, which leads to their weakness in traditional culture and lack of thorough understanding of the essence of traditional culture. Without a basic understanding and recognition of excellent traditional culture, it is impossible to truly feel the broad and profound Chinese culture, and lack the basic source of cultural self-confidence. College students have certain perceptual cognition to the mainstream culture of contemporary Chinese, but because the ideological understanding level is uneven, in intercultural communication and conflict, some students are not able to discern the correct direction of cultural development, the social mainstream value and belief attitude indifferent, understanding of socialism and communism is fuzzy, lack of confidence, appeared inconsistent the mainstream culture, perceptual cognition and rational recognition behavior recognition. As the ideological and political education is the most important means to publicize the idea of the Communist Party of China, it is duty bound to publicize the revolutionary culture. However, in the process of promoting the revolutionary culture, the means of publicity are too paradigmatic and rigid because of improper methods and other reasons. The means of propagandist and the benefit of heavy work are more than the effect of publicity. Contemporary college students' understanding of western culture mostly comes from the way of movies, dramas, novels and networks. They don't have personal experience and comprehensive understanding. Western culture is very superficial and superficial. Due to the lack of a comprehensive understanding and rational analysis of western culture, it is difficult to identify and resist the negative decadent ideas, so it is easy to praise blindly [3].

\subsection{Causes}

At present, the content of higher education is set up in terms of science and technology, humanities, application and foundation. There are relatively few courses in culture and education. Such a course setting is not conducive to the cultivation of College Students' humanistic spirit and the establishment of cultural confidence. At the same time, although the university set up the ideological and political theory courses and some humanities elective courses, but the mode of education content, pertinence, age is not strong, the cultural education and cultural resources lack of deep mining and utilization, only the cultural knowledge teaching and students, can lead students to make resonance. The students accepted culture. The influence of College Students' subjective factors is that contemporary college students are active in thinking, rich in information and receptive to new things. But due to their lack of life experience, they are often not fully aware of things. They are weak in distinguishing right from wrong, and are easily influenced by all kinds of social thoughts. At the same time, under the background of professional differentiation, college students' energy tends to focus more on professional knowledge learning, ignoring the learning and understanding of excellent traditional culture and advanced culture, which makes college students alienated and strangeness towards their own national culture. At present, China is still in the transition period of reform, the socialist market economic system is not perfect, utilitarianism, interests and other negative factors in market economy impact on the values of college students, some college students caused by the excessive pursuit of material interests and spiritual culture of cold contempt. Meanwhile, western developed countries have advocated their values and lifestyles with their strong economic strength, advanced scientific and technological means and developed cultural means. This method dispels some college students' identity to the mainstream culture of the country and weakens the mainstream values of college students [4]. 


\section{Integration Paths of Cultural Confidence Education and Ideological and Political Education}

\subsection{Integration of Excellent Traditional Culture and Ideological and Political Education}

The construction of the Chinese cultural discipline system and teaching material system is an important link in the integration of cultural confidence into the ideological and political education of colleges and universities. On the one hand, we should do well in compiling, publishing and popularizing the key textbooks of Chinese traditional culture. On the other hand, we must firmly resist the dissemination of Western misleading textbooks into our university classes. Western values are diverse and complex. Western values are diverse and complex. They reflect human intelligence and have false views of human nature, which are contrary to human civilization. As an important position in the field of ideology, the university must attach importance to the cultivation and development of advanced socialist culture. Some of the wrong ideas in the West are very harmful to the development of the cause of socialism with Chinese characteristics, and must stand firmly against them. The excellent traditional culture is the source of Chinese culture, which is the source of Chinese culture, and contains profound and profound ideological connotation. Excellent traditional culture includes the harmony between man and nature, the harmonious spirit of unremitting self-improvement enterprising spirit of justice and ideas, new innovative ideas pursuit and so on. They not only reflect the process of the development of Chinese history, but also reflect the creativity of Chinese culture. It is the cohesion and centrality of the Chinese nation. The excellent traditional culture plays an important role in shaping the national spirit. Ideological and political education workers in colleges and universities should strengthen the excavation and development of Chinese excellent traditional culture, so that can appreciate the endless charm and profound implication of traditional culture, and get spiritual nourishment from it. At the same time, based on maintaining the basic core of excellent traditional culture, we explore its modern expression mode and give new meaning to the times, so that Chinese excellent traditional culture will continue to carry forward in the new era.

\subsection{Integration of Elegant Campus Culture and Ideological and Political Education}

People interact with the environment, the environment affects people, and people also affect the environment. College students, ideological and political education, and cultural environment are three interrelated. Ideological and political education and cultural environment interact with college students to form a good mental image and spiritual outlook. Ideological and political education is the work of people. It is to cultivate people's career. People are the starting point and result of ideological and political education. The fundamental purpose of Ideological and political education is to promote college students' all-round development. With the help of cultural environment, ideological and political education chooses excellent cultural products and positive cultural activities with its own consciousness and advanced nature. It takes cultural environment as a carrier, innovating cultural forms. The cultural environment is based on the culture media, through the advanced cultural theory, outstanding cultural works, encouraging students, guide students to pursue lofty spirit, through cultural influence and penetration, make students get the inspiration of thoughts and art in the good cultural atmosphere to enjoy. Encourage college students to participate in the creation of campus culture. Through the establishment, overseas student art troupe and so on, more students can participate in the construction of campus culture, through dance, painting, works and other publicity and promotion of traditional culture and advanced culture. We can carry out ideological and political education through a lively and lively way. This can be a positive supplement to the traditional ideological and political education and broaden the space and scope of Ideological and political education. To improve the effectiveness of Ideological and political education is an effective way and means to integrate the cultural confidence into the ideological and political education.

\subsection{Integration of Advanced Mainstream Culture and Ideological and Political Education}

The advanced culture of socialism is the direction of College Students' cultural confidence. The advanced socialist culture under the guidance of Marx doctrine is a national, scientific and mass 
culture oriented to modernization, the world and the future. It provides spiritual power and intellectual support for socialist modernization. Only by vigorously developing advanced socialist culture, and constantly enhance our culture's international influence and competitiveness, to effectively protect the national ideology and cultural security. The ideological and political education workers should firmly grasp the essence Chinese characteristics of socialist advanced culture, innovation and development of the advanced culture communication platform, improve students' value recognition of the advanced socialist culture, consciously develop individual development and nation closer together. At the same time, we should encourage college students to participate in the practice of promoting the development of socialist culture and prosperity, and contribute to building a socialist cultural power. Therefore, we must firmly grasp the main grasp of the mainstream ideology of guiding college students to internalize the mainstream ideology. We should guide college students to grasp the methods and abilities of analyzing and discriminating diverse social thoughts. We should affirm their positive and reasonable factors with dialectical thinking, deny their decadent and negative aspects, and strengthen cultural confidence in the process of conscious internalization.

\subsection{Integration of Novel Network Culture and Ideological and Political Education}

The network culture is based on the network information technology, and the cultural activities, cultural ways, cultural products and cultural concepts formed in the network space. The network culture is the complex of the new technology and cultural content, and it is not appropriate to simply emphasize any one aspect. One is to look at culture from the point of view of the network, and the other is to look at the network from a cultural point of view. The former emphasizes the technical characteristics of the network, and highlights the cultural paradigm changes caused by technological change. The latter mainly starts from the characteristics of culture and emphasizes the transformation of cultural paradigm caused by the cultural attributes of the network content. The development of Internet has made the human society develop into a grid system. With the rapid development of Internet technology, all kinds of cultural forms and computer technology are integrated, and then the network culture has been spawned. In the era of Internet, all countries in the world are closely linked through the Internet. Different forms of Internet communities have become an important way for some western capitalist countries to spread their mainstream values. At present, to grasp the leading role of network culture discourse, universities should first grasp the development direction of socialist advanced culture and network culture, and thoroughly carry out the education of socialist core values through various media. It has a strong guiding role for college students' thinking and behavior. We should let the network culture play an open field of vision, cultivate the important role of innovative thinking, and enhance the cultural confidence of college students.

\section{Conclusions}

Cultural confidence is the cornerstone of the progress of the nation and the nation. Ideological and political education workers in Colleges and universities must actively study the current situation of College Students' lack of cultural confidence, and put forward the way to cultivate cultural confidence and ideological and political education. It can not only enhance the effectiveness of Ideological and political education, but also help the cultivation of college students' cultural confidence and promote the overall development of college students.

\section{References}

[1] Ye Qing. Cultivation of College Students Cultural Confidence under the Ideological and Political Education [J]. Social Sciences Journal of Universities in Shanxi, 2017, 29(10): 84-86.

[2] Duan Haichao. The Research on the Infulence towards the Direction of Development of the Ideological and Political Education in Higher Education by the Cultivation of Cultural Consciousness and Cultural Self-confidence [J]. Journal of National Academy of Education Administration, 2015(1): 47-50. 
[3] Cai Bin. Cultivating cultural self-confidence: an important dimension of improving the effectiveness of ideological and political education in colleges and universities [J]. Journal of Beijing Institute of Graphic Communication, 2017, 25(8): 147-149.

[4] Ma Baojuan, Liang Meiqi. Analysis of the path of cultural confidence into the ideological and political education [J]. Journal of Liaoning Normal University (Social Science Edition), 2018, 41(1): 104-109. 